\title{
Natural and Experimental Infections of Campylobacter cryaerophila in Rainbow Trout: Gross Pathology, Bacteriology, Clinical Pathology and Chemotherapy
}

\author{
Seyit Aydin*, Nejdet Gültepe and Harun Yildiz \\ Fisheries Faculty, Çanakkale Onsekiz Mart University, Karacaören, Çanakkale, Turkey
}

(Received January 28, 2000)

\begin{abstract}
Campylobacter cryaerophila was isolated from naturally infected rainbow trout (Oncorhynchus mykiss), and its pathogenicity was tested by intramuscular injection using 1-yearold rainbow trout and scattered mirror carp (Cyprinus carpio). C. cryaerophila did not induce experimental infection in scattered mirror carp. Natural and experimental infections caused mortalities in rainbow trout with gross clinical abnormalities such as exophthalmia, damage of liver, bloody kidney and haemorrhagic heart and swollen intestine. Glucose, cholesterol, triglyceride and haematocrit levels in blood of both naturally and experimentally infected fish were significantly decreased as compared to healthy fish. Significant decreases were observed in the serum glutamate oxalacetate transaminase level of experimentally infected fish and serum total protein value of naturally infected fish. Albumin levels of serum were not significantly different among the three treatments. Sensitivities of three isolates of $C$. cryaerophila against 51 chemotherapeutants were determined. Minimum inhibitory concentrations of formalin and enrofloxacin to the isolates were between $3.5-4.5 \mu \mathrm{L} / \mathrm{mL}$ and $0.025-1 \mu \mathrm{L} / \mathrm{mL}$, respectively. Oral applications of enrofloxacin after bath disinfections with formalin controlled the natural infections.
\end{abstract}

Key words: Campylobacter cryaerophila, rainbow trout, blood chemistry, haematocrit, chemotherapy, enrofloxacin

The species of Campylobacter genus can be found in the reproductive organs, intestinal tract, and oral cavity of humans and animals. Some species are pathogenic for humans and animals (Holt et al., 1994). Campylobacter cryaerophila was added as a new species in the 9th edition of Bergey's Manual of Systematic Bacteriology (Holt et al., 1994). No information is currently available regarding its isolation and/or pathogenicity in aquatic animals.

The blood parameters of fish are used as an indicator of their physiological state and its study has become widespread in control of pathologies caused by infectious diseases (Eiras and Saraiva, 1986; Studnicka and Siwicki, 1986; Grizzle and Kiryu, 1993; Nakano et al., 1995; Yokoyama et al., 1996; Rodger and Richards, 1998; Hrubec and Smith, 1999), nutritional factors (Eiras and Saraiva, 1986), toxic effects (Everall et al., 1991, 1992; Mughal et al., 1993; Ahmad et al., 1995; Shakoori

* Corresponding author et al., 1996), different stressors (Martinez et al., 1994), anoxic conditions and the other environmental factors in fish farming.

C. cryaerophila infections first occurred in three rainbow trout (Oncorhynchus mykiss) farms in 1997 and two rainbow trout farms in 1998 in Turkey. The isolates of C. cryaerophila were obtained from these naturally infected fingerling and juvenile rainbow trout.

The present study was designed to test the pathogenicity of $C$. cryaerophila isolates in rainbow trout and scattered mirror carp (Cyprinus carpio), and to investigate effects on blood parameters in naturally infected and experimentally infected rainbow trout. A secondary goal was to develop adequate quarantine and therapy techniques for control of this disease.

\section{Materials and Methods}

\section{Experimental tanks}

Three different $550 \mathrm{~L}$ capacity concrete basins sup- 
plied with freshwater circulation daily (once per day) and continuous aeration ( $9 \mathrm{ppm}$ dissolved $\mathrm{O}_{2}$ content) were used for the infection of rainbow trout and scattered mirror carp. The water temperatures were $16 \pm 1.5^{\circ} \mathrm{C}$ and $21 \pm 1^{\circ} \mathrm{C}$ in basins of rainbow trout and scattered mirror carp, respectively.

\section{Isolation and identification of bacteria}

Bacteria were isolated from naturally infected rainbow trout at different intervals during the spring and summer seasons in 1997 and 1998 at three fish farms designated as Farm 1, 2 and 3, respectively during routine necropsy.

For the isolation of bacteria, inocula were aseptically obtained from kidney, liver spleen, gills and bloody ascites of naturally infected fish and immediately streaked on enriched tryptic soya (TS) agar, BairdParker agar, Yersinia selective agar, thiosulphate citrate bile salt (TCBS) agar, Salmonella-Schigella (SS) agar, Pseudomonas-Aeromonas selective (GSP) agar, KLIGLER (KG) agar, MacConkey agar and Campylobacter selective agar. Incubations were generally carried out at $25^{\circ} \mathrm{C}$ for $1-7$ days.

Samples inoculated on Campylobacter selective agar were incubated at 25 and $30^{\circ} \mathrm{C}$ for $48 \mathrm{~h}$ in an anaerobic jar with the aid of Anaerocult ${ }^{\oplus} \mathrm{C}$ mini (Anonymous, 1996).

After initial incubation, individual colonies grown on Campylobacter selective agar were cultured on Campylobacter selective agar at $25^{\circ} \mathrm{C}$ for another $48 \mathrm{~h}$, and then inocula were re-streaked on the same agar media. Individual colonies were used in the identification tests (Plumb and Bowser, 1983; Austin and Austin, 1993; Anonymous, 1996). All of the bacteriological media used in this research was from Merck (Merck, Germany).

In vitro efficacy of some disinfectants and antibiotics

Each pure culture of isolated bacteria were added to sterile phosphate buffer solutions and their concentrations were adjusted with the use of a spectrophotometer as a $30 \%$ transmittance $(525 \mathrm{~nm})$ with sterile phosphate buffer. Aliquots $(0.1 \mathrm{~mL})$ were used to test the sensitivity of the bacterium to several chemotherapeutic and other antimicrobial substances. The agar disc diffusion method with enriched Campylobacter selective agar (Bauer et al., 1966) was employed to determine their sensitivity to chemotherapeutic agents (Table 2) according to National Committee for Clinical Laboratory Standards (NCCLS, 1992).

In vitro assays were conducted to determine the inhibitory concentrations of formalin, chloramine- $T$ and enrofloxacin. For the formalin and chloramine-T serial arithmetic dilutions from 120 to $0.4 \mu \mathrm{L} / \mathrm{mL}(\mu \mathrm{g} / \mathrm{mL}$ for chloramine-T) in test tubes containing $5 \mathrm{~mL}$ sterile phosphate buffer solution were prepared. Aliquots $(0.1 \mathrm{~mL})$ of the standardized bacterial isolates were added to each tube and left to stand at room temperature for $1 \mathrm{~h}$, after which a loopful material from each tube was inoculated onto plates containing Campylobacter agar medium. These were incubated for 3 days at $25^{\circ} \mathrm{C}$ and then examined for growth of $C$. cryaerophila (Cipriano et al., 1996). These plates were also incubated in the anaerobic jar with the aid of Anaerocult ${ }^{\circledR} \mathrm{C}$ mini. In a similar manner the inhibitory effect of the enrofloxacin (serial arithmetic dilutions from 10 to $0.012 \mu \mathrm{L} / \mathrm{mL}$, being left to standard for $1 \mathrm{~h}$ after inoculation) were tested. Control tubes containing sterile phosphate buffer were each inoculated with aliquots of the standardized bacteria and cultured onto Campylobacter selective medium for 3 days at $25^{\circ} \mathrm{C}$.

\section{Chemotherapy}

In order to treat naturally infected fish in rainbow trout farms, $20 \mathrm{mg} / \mathrm{kg}$ fish dosage of enrofloxacin (Baytril) per day was orally used for 5 days after application of formalin bath for 4 days $(80 \mathrm{~mL} L$ of water for 1 h).

\section{Experimental infections}

A total of 21 rainbow trout, 1-year-old with average $82.7 \pm 8.6 \mathrm{~g}$ body weight, were used for the experiment. Ten fish were injected with $C$. cryaerophila isolated from diseased rainbow trout in Farm 1. Following 20 days of preliminary adaptation period fish were in jected with $5 \times 10^{5}$ live cell into the muscle around dorsal fin. The remaining 11 fish were injected with sterile phosphate buffered saline (PBS). An identical method was used to infect scattered mirror carp (average 41.3 \pm $4.3 \mathrm{~g}$ body weight) with $C$. cryaerophila.

The inoculated bacterium (C. cryaerophila) was re-isolated from kidney of dead fish quantitatively by using Campylobacter selective agar and identified as $C$. cryaerophila by characterization tests.

\section{Clinical examination}

During the experiments of the natural and experimental infections, behaviours of the diseased fish as well as their gross external and internal symptoms were recorded.

\section{Sampling and analytical procedure of blood}

Blood analyses were conducted to compare blood parameters of fish using rainbow trout from each experimental group; 1) non-infected healthy 11 fish, 2) naturally infected 11 fish in Farm 1, and 3) experimentally infected 9 fish (moribund).

About $4 \mathrm{~mL}$ blood was drawn from the caudal vein by puncture and each sample immediately transferred into two sets $2 \mathrm{~mL}$ evacuated blood collection tubes (Terumo Europe N.V., Leuven, Belgium). One set of the collection tubes contained EDTA (ethylene diamine 
tetra acetic acid) to store the blood samples used to determine haematocrit $(\mathrm{Ht})$ values. The other set of collection tubes which did not contain EDTA were used for determination of biochemical characteristics. Blood in evacuated blood collection tubes was centrifuged promptly at $3100 \times \mathrm{g}$ for $10 \mathrm{~min}$. Glucose (GLC), colestherol (CHOL), triglyceride (TG), albumin (ALB), total protein (TP) levels in the serum were determined with colourometric methods by using Spinreact kits in $492 \mathrm{~nm}$ wavelengthy by AWARNES-Stat Fax 1904 Spectrophotometer. Glutamate oxalacetate transaminase (GOT) enzyme was determined by using Spinreact kits in $540 \mathrm{~nm}$ wavelengthy. Haematocrit $(\mathrm{Ht})$ values of blood samples were determined with Microhaematocrit method as outlined by Bullock (1989).

\section{Statistical analysis}

The data obtained from blood analyses was subjected to Mann-Whitney test for two independent samples using Minitab-User Quide package programme (Anonymous, 1993). A value of $P<0.05$ was considered to be significant.

\section{Results and Discussion}

\section{Clinical signs of naturally infected rainbow trout}

Post-mortem clinical signs determined in the naturally infected fish with $C$. cryaerophila were as follows;

There were haemorrhages at the base of fins and gill filaments, exophthalmia and cataract in eyes, and darkening of skin. Pale and dark areas in various places containing bloody and inflammatory exudate were observed in swollen kidney. The livers were pale and yellow in colour, and showed hyperaemic, haemorrhagic and necrotic areas. Stomach and intestine content analyses suggested that the diseased fish were starved for a long time. Furthermore, inflammation and haemorrhage in wall of swollen intestine and swim-bladder, haemorrhages in heart and membrane of heart, and enlarged spleen were observed.

\section{Identification of the bacteria}

All isolates (3 isolates) were identified using standard biochemical profiles as Campylobacter cryaerophila (Table 1). The biological and biochemical characteristics of the isolates confirmed that these slender and vibrioid cells had microaerophilic respiratory type of metabolism. The results were almost identical with those of isolates from human or other animals (Holt et al., 1994). Holt et al. (1994) reported that acidic and neutral end products of carbohydrates are not produced by Campylobacter species, which is also the case of the present study. Bacteria were additionally passaged on selective media and isolates did only grow on Campylobacter selective agar and TS agar in this study.
Results of antibiogram tests and MICs determination of disinfectants

Antimicrobial sensitivity of the isolates varied from isolates (Table 2). National Committee for Clinical Laboratory Standards (NCCLS, 1992) was used as a reference in the evaluation of antibiogram tests. $C$. cryaerophila isolated from fish in Farm 2 was sensitive to nalidixic acid, pefloxacine, doxycycline, chloramphenicol, ceftazidime, mezlocillin, ceftizoxime, aztreonam and cephaclor, and was resistant to tobramycin, kanamycin which contrasts to the findings of isolates isolated from fish in Farm 1 and 3 . According to the results of this study, norfloxacin, enrofloxacin, piperacillin, ofloxacin, enoxacin, netilmycin antibiotics could be recommended to treat fish infected with C. cryaerophila.

In vitro assays indicated that MICs were $3.75,4.5$ and $3.5 \mathrm{~mL} / \mathrm{L}$ of formalin and $0.0625,1$ and $0.025 \mathrm{~mL} / \mathrm{L}$ of enrofloxacin against $C$. cryaerophila isolates from Farm 1, 2 and 3, respectively, but chloramine-T was not effective to any isolates.

\section{Medical treatments}

About 30-100 fish had died per day when infection initially appeared in farms. Mortalities of the fish treated with formalin and enrofloxacin had remarkably reduced, and stopped in Farms 2 and 3 . Mortality rates of these farms were $10 \%$ and $8 \%$, however, mortalities continued for 3 months and reached about 53\% in Farm 1 where fish was not treated.

The dosage of formalin used in the present study was higher than dosages recommended (Austin and Austin, 1993; Scott, 1993) but no toxicity was observed for fish in this application.

\section{Pathogenicity of the isolate}

Nine of 10 rainbow trout infected with $C$. cryaerophila died in 23 days following the inoculation ( $90 \%$ mortality). No clinical signs or mortality were observed in non-infected control group injected with PBS in 2 months following the injection. The clinical signs of experimental infections such as exophthalmia, damage of liver, bloody kidney, haemorrhagic heart and swollen intestine in rainbow trout were similar to the signs observed in natural $C$. cryaerophila infection. In addition, there was degeneration of jaw and fins in experimentally infected fish, unlike the findings for the natural infection. Hepatosomatic index was $1.44 \pm 0.018$ in the dead fish of experimental infection group, and this was similar to that of normal fish in other reports (Shimma et al., 1982, 1984; Nakano et al., 1995). Also, rate of spleen weight to body weight (splenosomatic index) was $0.13 \pm 0.02 \%$.

The counts of $C$. cryaerophila in kidney from experimentally infected fish ranged from $8.1 \times 10^{5} \mathrm{CFU} / \mathrm{g}$ to . $5.8 \times 10^{10} \mathrm{CFU} / \mathrm{g}$, and Koch's postulates were satisfied.

No clinical signs or mortality were observed in the 
Table 1. Biological and biochemical characteristics of bacteria (Campylobacter cryaerophila) isolated from diseased rainbow trout

\begin{tabular}{|c|c|c|}
\hline \multirow[t]{2}{*}{ Characteristic } & \multicolumn{2}{|r|}{ Response } \\
\hline & 3 isolates & $\begin{array}{c}\text { Reference* } \\
\text { (Campylobacter cryaerophila) }\end{array}$ \\
\hline Gram stain & - & - \\
\hline Motility (at $25^{\circ} \mathrm{C}$ ) & + & + \\
\hline Sheathed flagella & - & - \\
\hline Growth at Yersinia selective agar & - & . \\
\hline at GSP agar & - & . \\
\hline at Baird-Parker agar & - & . \\
\hline at TCBS agar & - & . \\
\hline at KG agar & - & . \\
\hline at MacConkey agar & - & . \\
\hline at SS agar & - & . \\
\hline Aerobic growth on complex solid media (at TS agar) & + (microaerophilic) & + (microaerophilic) \\
\hline Morphology of colonies & Small, white & Small, white \\
\hline Morphology of cell & Rod & Rod \\
\hline Oxidase & + & + \\
\hline Catalase & + & + \\
\hline Growth at $25^{\circ} \mathrm{C}$ & + & + \\
\hline at $42^{\circ} \mathrm{C}$ & + & + \\
\hline at $15^{\circ} \mathrm{C}$ & + & + \\
\hline at $6 \% \mathrm{NaCl}$ & - & - \\
\hline at $3 \% \mathrm{NaCl}$ & - & - \\
\hline $\begin{array}{l}\text { Urease, Alkaline phosphatase and Arginine } \\
\text { dihydrolase }\end{array}$ & - & - \\
\hline Gelatin, Esculin and, Starch hydrolysis & - & . \\
\hline Degredation of Tween 20 and Tween 80 & - & . \\
\hline Production of $\mathrm{H}_{2} \mathrm{~S}$ & - & . \\
\hline Methyl-Red test & - & - \\
\hline Voges-Proskauer test & - & - \\
\hline Simmon's citrate & - & . \\
\hline Valin utilization & - & . \\
\hline $\mathrm{NO}_{3}$ reduced to $\mathrm{NO}_{2}$ & + & + \\
\hline $\mathrm{NO}_{2}$ reduction & - & - \\
\hline Growth at KCN & \pm & . \\
\hline Indole production & - & - \\
\hline $\begin{array}{l}\text { Acid/gas production from carbohydrates (glucose, lactose, } \\
\text { melibiose, maltose, arabinose, inositol, rhamnose, } \\
\text { fructose, sucrose, mannitol, sorbitol, xylose, sorbose, } \\
\text { mannose, galactose, dulcitol, trehalose, salicin, dextrin, } \\
\text { inulin, glycogen, erythritol, raffinose, adonitol) }\end{array}$ & $-1-$ & - \\
\hline
\end{tabular}

Table 2. Results of susceptibility test of Campylobacter cryaerophila isolates to chemotherapeutants

Chemotherapeutics $(\mu \mathrm{g} / \mathrm{disc})$ against which all 3 isolates were sensitive

Ceftriaxone (30), Piperacillin (100), Enrofloxacin (15), Enoxacin (10), Netilmycin (30), Imipenem (10), Norfloxacin (10), Ofloxacin (5).

Chemotherapeutics ( $\mu \mathrm{g} / \mathrm{disc})$ against which 2 isolates were sensitive

Ceftazidime (30), Cephoperazone (75), Pefloxacine (5), Tobramycin (10), Ciprofloxacin (5), Kanamycin (30), Gentamycin (10),

Cephalothin (30), Amycacine (30), Cephoperazone/Sulbactam (75/30).

Chemotherapeutics $(\mu \mathrm{g} / \mathrm{disc})$ against which one isolate was sensitive

Nalidixic acid (30), Doxycycline (30), Carbenicillin (100), Azitromycin (15), Trimethoprim/Sulphamethoxazole (1.25/23.75),

Chloramphenicol (30), Cephradine (30), Mezlocillin (75), Thiamphenicol (30), Cephadroxil (30), Cephaclor (30), Cephtizoxime (30), Cephalexine (30), Aztreonam (30), Cefotaxime (30), Cefuroxime (30).

Chemotherapeutics ( $\mu \mathrm{g} / \mathrm{disc}$ ) against which no isolate was sensitive

Methicillin (5), Clindamycin (2), Rifampycin SV (30), Amphicillin (10), Novobiocin (30), Azlocillin (75), Lincomycin (2), Tetracycline (30), Vancomycin (30), Amoxycillin (25), Oxacillin (5), Clarithromycin (15), Cefixime (5), Cephazolin (30), Amoxycillin/Clavulanic acid (20/10), Penicillin G (10 1u), Cephoxitin (30), Erythromycin (15). 
scattered mirror carp injected with $C$. cryaerophila in 2 months following the bacterial inoculation.

\section{Blood analysis}

The purpose of blood analysis was to determine the alterations of blood components in response both to natural and experimental infections and to investigate the possibility of diagnosing the disease using blood criteria as summarised in Table 3.

Serum GOT levels: The serum GOT level of experimentally infected fish group was significantly lower $(P<$ $0.01)$ than that of naturally infected and healthy fish (Table 3). No significant differences $(P>0.05)$ in the serum GOT levels were observed between healthy and naturally infected fish groups (Table 3). Although the serum GOT values may increase with acute infections (Studnicka and Siwicki, 1986), haematotoxic effects (Everall et al., 1991) and motile Aeromonas septicaemia (Grizzle and Kiryu, 1993), it can also dramatically decrease in chronic stress (Nakano et al., 1995; Jeney et al., 1996) and toxic effects of pollution (Mughal et al., 1993; Ahmad et al., 1995; Shakoori et al., 1996). In this study, the decrease in serum GOT activity in the experimental infection might be attributed to the dysfunction of liver. Because activities of hepatic enzymes such as GOT, GPT and LDH in serum of fish are known to be very useful as an index for diagnosis of liver function (Everall et al., 1991, 1992; Nakano et al., 1995).

GLC values: The blood GLC level of experimentally infected fish group was the lowest among the all treatments $(P<0.01)$ compared to others, and also significant differences in the value were observed $(P<0.05)$ between naturally infected and healthy fish groups (Table 3). The low GLC levels in naturally and experimentally infected fish groups may come from hypoglycaemia due to the increase or decrease in activities of liver enzymes under stress given by the infection. This theory may be supported by the results of serum enzyme analysis showing a significant dec- rease of GOT level in serum of experimentally infected fish and the unsignificant increase of this enzyme in naturally infected fish. Also, the decreases in blood GLC may account for degeneration of muscular tissue. The blood GLC level of the healthy fish group shows no disagreement with the literature values (Goss and Wood, 1988; Haman and Weber, 1996; Hrubec and Smith, 1999). Blood GLC level in fish is known to be very useful as a criteria for diagnosis of liver and muscle tissues function (Shakoori et al., 1996).

CHOL levels: The serum $\mathrm{CHOL}$ values were significantly lower in experimentally infected $(P<0.01)$ and naturally infected fish $(P<0.05)$ compared with healthy fish (Table 3). This may be as a result of the infection, because no significant difference in the $\mathrm{CHOL}$ levels was observed between naturally infected and experimentally infected fish groups. Although effect of infections on serum $\mathrm{CHOL}$ values has not been reported by previous researchers, it is known that $\mathrm{CHOL}$ may decrease due to effects of toxic agents (Everall et al., 1991, 1992; Mughal et al., 1993). In the present study, the serum $\mathrm{CHOL}$ level of healthy group was within normal limits described by Shimma et al. (1984).

TG values: TG levels were significantly lower in experimentally infected $(P<0.01)$ and naturally infected fish $(P<0.05)$ compared with healthy fish while it was not significantly different $(P>0.05)$ between two infected fish group (Table 3). A correlation was observed between changes of serum TG and $\mathrm{CHOL}$ levels. It is known that $\mathrm{CHOL}$, lipoproteins and TG values are related with one another, and these are connected with metabolism of lipids and functions of liver and kidney in mammalian (Mayes, 1993), but further studies are needed to explain these biochemical characteristics of fish. In this study, the serum TG levels in healthy fish seem to be within the normal limits (Jeon et al., 1995).

TP levels: TP value in the serum of naturally infected fish group was significantly lower $(P<0.05)$ than that of healthy fish group (Table 3 ). Also, TP level of

Table 3. Mann-Whitney test for two independent results on blood biochemical parameters and $\mathrm{Ht}$ values of naturally infected, experimentally infected and healthy fish groups (minimum and maximum values in parentheses)

\begin{tabular}{|c|c|c|c|}
\hline Test & $\begin{array}{l}\text { Naturally infected fish }{ }^{1} \\
\qquad(\mathrm{n}=11)\end{array}$ & $\begin{array}{c}\text { Experimentally } \\
\text { infected fish }{ }^{2}(n=9)\end{array}$ & $\begin{array}{l}\text { Healthy fish } \\
\quad(n=11)\end{array}$ \\
\hline GOT (u/L) & 305 (165-379) & $17.2^{* *}(0.5-48.3)$ & $276.4(49.5-387)$ \\
\hline $\mathrm{GLC}(\mathrm{mg} / \mathrm{dL})$ & $31^{*}(10.7-53.8)$ & $4.9^{* *}(0-23.7)$ & $60.3(0.4-407.9)$ \\
\hline $\mathrm{CHOL}(\mathrm{mg} / \mathrm{dL})$ & $54 * *(13.3-245)$ & $75^{*}(25.3-205)$ & $133.3(88.5-467)$ \\
\hline $\mathrm{TG}(\mathrm{mg} / \mathrm{dL})$ & $88^{*}(8.5-402)$ & $95^{* *}(25.3-205)$ & $237(88.5-467)$ \\
\hline $\mathrm{TP}(\mathrm{g} / \mathrm{dL})$ & $2.5^{*}(1.1-6.2)$ & $4.1(1-5.2)$ & $4.3(1.8-6.5)$ \\
\hline ALB $(g / d L)$ & $1.7(0-2.8)$ & $2.1(0-3.1)$ & $2.1(1.5-2.5)$ \\
\hline $\mathrm{Ht}(\%)$ & $31.4^{* *}(12.8-47)$ & $33^{* *}(10-43)$ & $40(31-55)$ \\
\hline
\end{tabular}

${ }^{1}=$ the fish showing clinical signs.

${ }^{2}=$ in the moribund stage.

$\mathrm{n}=$ number of samples examined.

$*=P<0.05$

$* *=P<0.01$ 
experimentally infected fish was lower, though not statistically significant, than that of healthy fish. The mean serum TP of healthy fish was within the normal limits given in rainbow trout (Goss and Wood, 1988; Wang et al., 1994; Jeon et al., 1995; Hrubec and Smith, 1999).

$A L B$ values: Serum ALB level of the naturally infected fish group was lower than those of healthy and experimentally infected fish (Table 3 ) but no statistically significant differences $(P>0.05)$ were observed among the treatments. These mean serum levels of ALB in the three fish groups were within the normal limits as indicated in rainbow trout (Jeon et al., 1995; Hrubec and Smith, 1999). Further studies are needed to explain effects of $C$. cryaerophila infection on serum proteins, and researches should include other serum proteins such as globulins.

$H t$ levels: There were decreases in the $\mathrm{Ht}$ values both in naturally infected $(P<0.01)$ and experimentally infected $(P<0.05)$ fish groups compared to healthy fish group (Table 3). Significant decreases in blood $\mathrm{Ht}$ levels of infected fish groups may be a consequence of accelerated erythrocyte lysis due to bacteria. The lower levels of $\mathrm{Ht}$ could be expected in fish groups infected with bacteria (Eiras and Saraiva, 1986; Martinez et al., 1994; Rodger and Richards, 1998) and parasites (Yokoyama et al., 1996). There were no significant difference in the $\mathrm{Ht}$ values between naturally infected and experimentally infected fish groups. Wide ranges of variation in the blood haematocrit values of naturally infected and experimentally infected fish groups may also originate from effect of the infection.

In conclusion, the present results demonstrated that C. cryaerophila could be a pathogen for rainbow trout but not for scattered mirror carp. Further studies however are necessary using different environmental conditions. The most discernible signs of natural and experimental infections were exophthalmia, pale liver, bloody kidney, haemorrhagic heart and swollen intestine. Another point of this study is that both natural and experimental infections of $C$. cryaerophila could cause the decrease in GLC, CHOL, TG and $\mathrm{Ht}$ values in blood of rainbow trout while TP level in natural infected fish and GOT level in experimentally infected fish showed significantly decreases from that of healthy fish. The chemotherapy with enrofloxacin after formalin bathes provided complete recovery of the naturally infected fish in treatment applied farms.

\section{References}

Ahmad, F., S. S. Ali and A. R. Shakoori (1995): Sublethal effects of danitol (Fenpropathrin), a synthetic pyrethroid, on Chinese grass carp, Ctenopharyngodon idella. Folia Biologica (Kraków), 43, 151-159.

Anonymous (1993): Minitab for Windows. Minitab Release 9.2, Minitab Inc. Minitab-User Quide.

Anonymous (1996): Microbiology manual. Merck, E. Merck,
Darmstad, $405 \mathrm{pp}$.

Austin, B. and D. A. Austin (1993): Bacterial fish pathogens-disease in farmed and wild fish. Second Edition, Ellis Horwood, London (UK), $376 \mathrm{pp}$.

Bauer, A. W., W. M. Kirby, J. C. Sherris and M. Turck (1966): Antibiotic susceptibility testing by a standardized single disc method. Amer. J. Clin. Pathol., 45, 493-496.

Bullock, A. M. (1989): Laboratory methods, In "Fish pathology" (ed. by R. J. Roberts). Baillière \& Tindall, London (UK), pp. 374-405.

Cipriano, R. C., L. A. Ford, C. E. Starliper, J. D. Teska, J. T. Nelson and B. N. Jensen (1996): Control of external Aeromonas salmonicida: Topical disinfection of salmonids with Chloramine-T. J. Aquat. Anim. Health, 8, 52-57.

Eiras, J. C. and A. Saraiva (1986): Nutritional factors as the cause of an outbreak of Pseudomonas fluorescens in rainbow trout, Salmo gairdneri Richardson. Publicações do Inst. De Zoologia 'Dr. Augusto Nobre' Faculdade de Ciências do Porto, 192, 1-8.

Everall, N. C., C. G. Mitchell, D. B. Groman and J. A. A. Johnston (1991): Tracing of haematotoxic agents in water with the aid of captive fish: a study captive adult Atlantic salmon Salmo salar in the River Don, Aberdeenshire, Scotland. Dis. Aquat. Org., 10, 75-85.

Everall, N. C., C. G. Mitchell and J. N. Robson (1992): Effluent causes of the 'pigmented salmon syndrome' in wild adult Atlantic salmon Salmo salar from the River Don in Aberdeenshire. Dis. Aquat. Org., 12, 199-205.

Goss, G. G. and C. M. Wood (1988): The effects of acid and acid/aluminium exposure on circulating plasma cortisol levels and other blood parameters in the rainbow trout, Salmo gairdneri. J. Fish Biol., 32, 63-76.

Grizzle, J. M. and Y. Kiryu (1993): Histopathology of gill, liver, and pancreas, and serum enzyme levels of channel catfish infected with Aeromonas hydrophila complex. J. Aquat. Anim. Health, 5, 36-50.

Haman, F. and J. M. Weber (1996): Continuous tracer infusion to measure in vivo metabolite turnover rates in trout. $J$. Exp. Biol., 199, 1157-1162.

Holt, J. G., N. R. Krieg, P. H. A. Sneath, J. T. Staley and S. T. Willams (1994): Bergey's Manual of Determinative Bacteriology. Ninth Edition, Williams \& Wilkins, Baltimore, Maryland (USA), pp. 175-190.

Hrubec, T. C. and S. A. Smith (1999): Differences between plasma and serum samples for the evaluation of blood chemistry values in rainbow trout, channel catfish, hybrid tilapias, and hybrid stripped bass. J. Aquat. Anim. Health, 11, 116-122.

Jeney, Z., E. T. Valtonen, G. Jeney and E. I. Jokinen (1996): Effects of pulp and paper mill effluent (BKME) on physiology and biochemistry of the roach (Rutilus rutilus L.). Arch. Environ. Contamin. Toxicol., 30, 523-529.

Jeon, J. K., P. K. Kim and H. T. Huh (1995): Storage stability of blood constituents in fish. J. Korean Fish. Soc., 28, 131136.

Martinez, F. J., M. P. Garcia-Riera, M. Canteras, J. De Costa and S. Zamora (1994): Blood parameters in rainbow trout (Oncorhynchus mykiss): simultaneous influence of various factors. Comp. Biochem. Physiol., 107, 95-100.

Mayes, P. A. (1993): Bioenergetics, metabolisms of lipids and carbonhydrates, In "Harper's biocehmistry" (ed. by R. K. Murray, P. A. Mayes, D. K. Granner and V. W. Rodwell). Appleton \& Lange Publication, Newyork (USA), pp. 128332.

Mughal, A. L., M. J. Iqbal and A. R. Shakoori (1993): Toxicity of short term exposure of sublethal doses of a synthetic pyrethroid, fenvalerate, on the Chinese grass carp, 
Ctenopharyngodon idella. Proc. Symp. Aquat. Dev. in Pakistan, 49-74.

Nakano, T., M. Tosa and M. Takeuchi (1995): Improvement of biochemical features in fish health by red yeast and synthetic astaxantin. J. Agricult. Food Chem., 43, 15701573.

National Committee for Clinical Laboratory Standards (NCCLS, 1992): Fourth international supplement., 12, 20.

Plumb, J. A. and P. R. Bowser (1983): Microbial Fish Disease Laboratory Manual. Brown Printing Company Montgomery, Alabama (USA), $83 \mathrm{pp}$.

Rodger, H. D. and R. H. Richards (1998): Observational study of erythrocytic inclusion bodies in farmed Atlantic salmon, Salmo salar L., in British Isles. J. Fish Dis., 21, 101-111.

Scott, P. (1993): Therapy in aquaculture, In "Aquaculture for veterinarians" (ed. by L. Brown). Pergamon Press, New York (USA), pp. 131-152.

Shakoori, A. R., A. L. Mughal and M. J. Iqbal (1996): Effects of sublethal doses of fenvalerate (a synthetic pyrethroid) administered continuously for four weeks on the blood, liver and muscles of a freshwater fish, Ctenopharyngodon idella. Bull. Environ. Contamin. Toxicol., 57, 487-494.
Shimma, Y., H. Shimma and K. Ikeda (1982): Plasma constituents of 2-year-old rainbow trout raised with fish meal and SCP combined feeds. Bull. Nat. Res. Inst. Aquacult., 3, 61-73.

Shimma, Y., H. Shimma, K. Ikeda, T. Akiyama and R. Suzuki (1984): A rearing test of 2-year-old rainbow trout in a $15^{\circ} \mathrm{C}$ pond from June to spawning in December with reference to plasma constituents. Bull. Nat. Res. Inst. Aquacult., 6, 33-43.

Studnicka, M. and A. Siwicki (1986): Physiological condition of ripe sea trout Salmo trutta m. trutta on the basis of selected hematological and biochemical parameters. Bull. Sea Fisheries Institute (Gydnia), 17, 8-10.

Wang, Y., G. J. F. Heigenhauser and C. M. Wood (1994): Integrated responses to exhaustive exercise and recovery in rainbow trout white muscle: acid-base, phosphogen, carbonhydrate, lipid, ammonia, fluid volume and electrolyte metabolism. J. Exp. Biol., 195, 227-258.

Yokoyama, H., T. Danjo, K. Ogawa, T. Arima and H. Wakabayashi (1996): Hemorrhagic anemia of carp associated with spore discharge of Myxobolus artus (Myxozoa: Myxosporea). Fish Pathol., 31, 19-23. 